\title{
Can Gender Differences in Distributional Preferences Explain Gender Gaps in Competition? ${ }^{1}$
}

\author{
Utteeyo Dasgupta \\ Department of Economics, Wagner College, NY, USA \\ Center for International Policy Studies, Fordham University, NY, USA \\ utteeyodasgupta@gmail.com
}

\section{Subha Mani}

Department of Economics and Center for International Policy Studies, Fordham University, NY, USA

Population Studies Center, University of Pennsylvania, PA, USA

IZA, Bonn, Germany

smani@fordham.edu

\section{Smriti Sharma (corresponding author)}

Newcastle University Business School, Newcastle Upon Tyne, UK

Smriti.sharma@newcastle.ac.uk

Phone: +358465231395

\section{Saurabh Singhal}

Lancaster University, Lancaster, UK

s.singhal1@lancaster.ac.uk

\footnotetext{
${ }^{1}$ We acknowledge support from UNU-WIDER and IGC-India Central. We thank the editors and a reviewer as well as seminar participants at Monash University and Fordham University for comments. Neha Agarwal, Riju Bafna, Piyush Bhadani, Japneet Kaur and Anshul Yadav provided excellent research assistance. We are grateful to the staff at the various colleges in the University of Delhi for lending their support in conducting the study. IRB clearance was obtained from Fordham University. The usual disclaimer applies.
} 


\section{Introduction}

Winning a competition has obvious economic benefits. However, competition is inherently inequality inducing, creating a divided society of winners and losers (Frank, 1996). Consequently, a distaste for inequality might encourage individuals to stay away from competitive environments, apprehensive of the disutility from an unequal outcome. Fehr and Schmidt (1999) point out however that individuals might have different preferences towards advantageous and disadvantageous inequalities. Consequently, attitudinal differences towards advantageous and disadvantageous inequalities can influence choices differently (Beranek, Cubitt, Gächter, 2015; Teyssier, 2008).

The relationship between competitiveness and distributional preferences assumes further importance in retrospect with the evidence from the experimental literature. First, experimental results consistently find females to be less inclined to compete than males (Niederle and Vesterlund, 2007; Flory, Leibbrandt and List, 2015; Buser, Niederle and Oosterbeek, 2014). Second, the literature generally finds women to be more egalitarian than men (Andreoni and Vesterlund, 2001; Dufwenberg and Muren, 2006; Engel, 2011; Sharma, 2015).

The existing literature has largely focused on examining gender gaps in competitiveness, controlling for variations in characteristics such as risk preferences, confidence, personality traits, family background, and session composition (e.g., Croson and Gneezy, 2009; Niederle, 2016; Niederle and Vesterlund, 2011). However, the extent to which gender gaps in competitiveness are explained by gender differences in distributional preferences remains understudied. A few papers explore distributional preferences as plausible mechanisms for explaining gender differences in competitiveness, but do not delve into gender-differentiated effects of distributional preferences. For instance, Balafoutas, Kerschbamer and Sutter (2012) classify a small sample of Austrian university subjects into inequality averters, efficiency seekers, inequality lovers, and spiteful agents, and find that spiteful and inequality-averse subjects avoid tournaments when given a choice. Additionally, upon controlling for these distributional preferences, risk attitudes, overconfidence and past performance, the gender difference in competitive behavior disappears. Kamas and Preston (2015) explore behavior in a battery of economic games as a function of distributional preferences measured using a three-person dictator game with US university students. They examine the choice among three compensation schemes (egalitarian, piece rate, and competitive payments) as a 
function of their social categorizations as self-interested, inequity averting, or efficiency maximizing decision-makers. ${ }^{1}$ They find women to be no more likely to choose the piece rate scheme over the competitive scheme; women appear to be significantly more likely to choose the equal pay over competitive pay than men, but that gender difference is explained away upon adding controls for confidence. Using data from a real-effort task played over multiple rounds, Gill and Prowse (2014) find that women decrease work effort after winning a large prize, and they suggest that this response to a competitive outcome may be explained by their distributional preferences (influenced by guilt or through egalitarian preferences).

In this paper, we contribute to this relatively small literature on distributional preferences and competitiveness by focusing on the following three issues: first, we are interested in understanding the relationship between distributional preferences and competitive choices. To that end, we categorize distributional preferences into preference for favorable inequality and aversion to unfavorable inequality (or behindness aversion). Note that an observed distaste for competition need not necessarily stem from distaste towards unequal outcomes; instead it can also be due to a lack of confidence and/or risk aversion (Bartling et al., 2009). We hypothesize that after controlling for confidence, risk preferences and other observable characteristics, a preference for favorable inequality should positively affect willingness to compete; behindness aversion in contrast, might be negatively related to willingness to compete. That is, subjects who prefer to be ahead of others would self-select into competition that allows them the opportunity to get ahead. In contrast, a subject who does not like to be left behind might like to avoid competitive environments that can lead to such an outcome. ${ }^{2}$

Second, we find that the existing literature have not typically delved into gendered differences in family background, behavior (including distributional preferences), and personality in explaining gender differences in competitive choices. Typically, the binary variable for gender in regressions reflects the male-female gap in competitiveness after controlling for other characteristics. But such

\footnotetext{
${ }^{1}$ Their compensation choices have an interesting design in that they introduce externality effects of subject choices for other members in a four-person group. Hence subject choices do not capture competitiveness in isolation, as in Niederle and Vesterlund (2007) where the decision-maker's choices do not have payoff implications for other members in the session.

${ }^{2}$ Note though, this is not necessarily the only behavioral hypothesis. It is plausible that a behindness averse person may be influenced by peers' choices, such that as peers' willingness to compete increases, a behindness averse person may be motivated to compete as well in apprehension of falling behind.
} 
regressions assume that the influence of these right-hand side (RHS) characteristics on one's willingness to compete remains identical for males and females, which is often not realistic. It is important to control for this heterogeneity, especially in the presence of multi-dimensional gender inequalities prevailing in many developing countries. For example, in the case of India, which constitutes the setting of our study, there is consistent evidence of skewed sex ratios disfavoring females at birth. Even among surviving children, females are more likely to be neglected in health and education related investments (e.g., Jayachandran, 2015). Further, high levels of gender inequality may cause males and females to internalize societal norms and expectations differently. This may lead women to believe that competitiveness is an undesirable trait, or that their decision to compete will not be positively rewarded by society (Andersen, Ertac, Gneezy, List and Maximiano, 2013; Barry, 2016). In such a situation, it is important to include gender-differentiated effects of characteristics to evaluate nurture-based differential investments that lead to male-female gaps in competitiveness. To allow for the effects of these characteristics to vary by gender, we interact the female dummy with distributional preferences and the full vector of controls that have been introduced in the previous literature to further explain gender gaps in competitive choices in our framework.

Third, we measure and explore the role of personality traits (Big Five and Locus of Control) as potential determinants of competitive choices. Studies on occupational choice find that one's preferences and traits such as risk-taking propensity, Big Five, innovativeness, and Locus of Control determine entry into inherently uncertain activities such as entrepreneurship (Caliendo et al., 2014; Cobb-Clark and Tan, 2011; Mueller and Thomas, 2000). More recently, experimental evidence also shows that Big Five personality traits determine behavior in a variety of games in the lab (Bartling et al., 2009; Cubel et al., 2016; Gill and Prowse, 2016; Müller and Schwieren, 2012). To the best of our knowledge, other studies have not explored the importance of locus of control as a determinant of competitive preferences.

Using a large sample of approximately 2,000 subjects at colleges in University of Delhi in India, we observe at first blush a significantly negative relationship between egalitarian distributional preferences and willingness to compete. Upon disentangling these egalitarian distributional choices into preference for favorable inequality and behindness aversion, we find that the choice to compete is negatively related to behindness aversion, and preference for favorable inequality positively 
determines the choice of the tournament wage scheme. ${ }^{3}$ Interestingly, when we disaggregate behavior along gender lines, we find behindness averse females are almost 13 percentage points more willing to compete than behindness averse males. In contrast, there is no gender difference in the relationship between preference for favorable inequality and willingness to compete. We follow up with standardized regressions to assess the relative importance of various factors in explaining gender gaps in competitiveness, and find that gender differences in distributional preferences and Big Five measures of conscientiousness and emotional stability are the most economically and statistically significant effects in our sample. Our results suggest that the gender gap in competitiveness observed in the literature could be driven by gendered differences in distributional preferences and selected personality traits that are developed during one's lifetime.

\section{Experiment Design}

Our study design consisted of two parts: in the first part, subjects participated in a series of incentivized tasks, and in the second part, they completed a survey. Each subject participated in all tasks and no feedback was provided between tasks. The first task, adapted from Bartling et al. (2009) measured subjects' competitiveness, confidence, and ability. In this task, the subjects had to participate in a real effort task that involved adding up four two-digit numbers. After a 30-seconds practice round, participants were asked to predict their performance in the 90-seconds actual task in advance and also choose between a piece-rate and tournament compensation scheme. Under the piece-rate scheme, Rs. 10 was paid for every correctly solved problem. Under the tournament scheme, Rs. 20 was paid for every correct answer if the subject out-performed a randomly selected student of the university who had solved the questions earlier. ${ }^{4}$ Note that our competition task by design minimizes possible issues of strategic competition where a subject's tournament entry decision depends on entry choices of other members in the group. ${ }^{5}$ Hence, the choice of tournament compensation can be interpreted as an inherent desire to compete. Accordingly, we define compete

\footnotetext{
${ }^{3}$ Bartling, Fehr, Marechal and Schunk (2009) find a negative relationship between preferences for egalitarian choices and competitiveness. Moreover, subjects that are averse to advantageous inequality or being ahead are significantly less likely to select into competition. However, as their small sample consists of only women, they are unable to comment on gender differences.

${ }^{4}$ We implemented the real effort math task among forty students from the university. We use the performance of these students for comparison in the tournament wage scheme.

5 We use a one-shot game where subjects make entry decisions simultaneously, without knowledge of other participants' entry decisions. Hence, by design we try to minimize the influence of peer effects (in the form of imitation) on entry decision.
} 
as a dummy that takes a value 1 if the subject chose the tournament compensation scheme and 0 if the subject chose the piece-rate compensation scheme. We define confidence as a dummy that takes a value 1 if the subject believes ex-ante that her performance in the actual task will exceed those of others in the university, 0 otherwise. We define task-related ability as the number of correct answers in the practice task.

In the second task, distributional preferences were measured using a framework adapted from Fehr, Bernhard and Rockenbach (2008) that asks subjects to state their preferences using a series of four binary distributional choices that would affect their and an anonymous participant's earnings. To rule out any order effects, we randomized the sequence in which these distributional choices were presented across sessions. As can be seen in Table 1, in all four choices, option $\mathrm{A}$ is an equal distribution, and option $\mathrm{B}$ is an unequal distribution. In row 1, a subject chooses between an allocation $(200,200)$ and $(200,120)$, and choosing the equal option is consistent with prosocial behavior since the subject can increase her partner's payoff in a costless manner. In row 2, choosing $(200,200)$ over $(320,80)$ indicates costly prosocial behavior on the part of the subject since she incurs a pecuniary cost on herself. In row 3, choosing $(200,200)$ over $(200,360)$ reflects envious behavior by the subject. Similar to Bartling et al. (2009) and Bauer, Chytilova and Pertola-Gebicka (2014), we supplement the framework by including row 4 where choosing $(200,200)$ over $(220$, 360) indicates the subject's willingness to incur pecuniary costs to ensure that her outcome is not relatively unfavorable, reflecting costly envy. Payment was based on decisions in one of the randomly chosen rows. We define egalitarian as a dummy that takes a value 1 if the subject chooses the equal division (option A) in each row, 0 otherwise. Further, we evaluate whether preference for favorable inequality influences competitive choices differently than an aversion for unfavorable inequality and we hypothesize the following: a person with a preference for favorable inequality is always envious, and would never like to be prosocial as defined in our distribution game. So, we define subjects exhibiting a preference for favorable inequality, that is, favorable inequality takes a value 1 , if they choose the equal distribution in both the envy and costly envy rows and choose the unequal distribution in both the prosocial and costly prosocial rows, 0 otherwise. We also posit that a subject averse to disadvantageous inequality is always envious but there are no restrictions on their prosocial behavior. Consequently, we define a subject as behindness averse if she chooses the equal distribution in both the envy and costly envy games, and there are no restrictions on choices in prosocial and costly prosocial rows. Note that our 
characterization of the two sides of inequality aversion are slightly different than the way they have been defined and characterized previously using this distribution game. ${ }^{6}$

\section{[Table 1 here]}

To measure risk preferences, we used the investment game of Gneezy and Potters (1997). Subjects allocated a portion of their endowment (Rs. 150) to a risky lottery and set aside the remainder. If they won the lottery based on a roll of a dice, the invested amount was tripled and they also got any amount they set aside. If they lost the lottery, they only received the amount that was set aside. We define risk preference as the proportion allocated to the risky lottery in the investment game where relatively higher invested amounts indicate relatively lower degrees of risk aversion.

In the second part of the study, we implemented a socioeconomic survey that collected details on family background and personality traits. To measure 'fluid intelligence', i.e., the ability to solve novel problems, we implemented a 10-item version of the Raven's progression matrices test, which is considered a good measure of nonverbal cognitive skill. To measure personality traits, we administered the Big Five inventory (Gosling et al., 2003). The traits in the Big Five are defined as follows: Openness to experience is the tendency to be open to new aesthetic, cultural or intellectual experiences. Conscientiousness refers to a tendency to be organized, responsible, and hard working. Extraversion relates to an outward orientation rather than being reserved. Agreeableness is related to the tendency to act in a cooperative and unselfish manner. Emotional stability (opposite of Neuroticism) is predictability and consistency in emotional reactions with absence of rapid mood changes. We also administered the Locus of Control questionnaire which ascertains the extent to which individuals believe they can control events affecting them (Rotter, 1966). Those believing that life's outcomes are due to their own efforts have a higher score on the locus of control (i.e., an internal locus of control), while those believing that outcomes are due to external factors (such as luck) have a lower score on the locus of control measure (i.e., an external locus of control). We standardize all personality traits using the mean and the standard deviation of the respective trait in the sample.

We conducted our study among a large sample of undergraduate students enrolled across 15

\footnotetext{
${ }^{6}$ Using the same distributional game, Bartling et al. (2009) disentangle egalitarian preferences into aversion to advantageous inequality (aheadness aversion) and aversion to disadvantageous inequality (behindness aversion).
} 
colleges in University of Delhi, India. Each subject participated only once in the study. Overall, we conducted 60 sessions with approximately 2,000 subjects, resulting in around 35 subjects per session. Each session lasted about 75 minutes. All subjects received a show-up fee of Rs. 150. The average additional payment was Rs. 230. Further, to minimize wealth effects, additional payments were based on one of the randomly chosen incentivized tasks. Subject instructions are available in the Appendix.

\section{Results}

\subsection{Summary Statistics}

We report summary statistics in Table 2 for the pooled sample as well as for males and females separately. Results from our incentivized games indicate that around a third of our subjects chose the tournament wage scheme with significant gender differences in this choice. Male subjects are about 15 percentage points more likely to choose the tournament compensation compared to females (p-value $<0.001$ ). In our distributional preference task, only 15 percent of the subjects always chose the equal outcome and there is no significant difference in the proportion of male and female subjects choosing the equal outcome $(\mathrm{p}$-value $=0.635)$. A higher proportion of subjects appear to be behindness averse (62 percent) than preferring favorable inequality ( 22 percent). A significantly higher proportion of females compared to males are behindness averse (p-value < 0.001 ) though there is no gender difference in favorable inequality ( $p$-value $=0.15$ ). Figure 1 describes the results.

\section{[Figure 1 here]}

A significantly (p-value $<0.001)$ higher proportion of non-egalitarian subjects $(33$ percent) chose to compete compared to egalitarian subjects (21 percent). Further, as Figure 2 shows, 33 percent of subjects preferring favorable inequality, and 28 percent of behindness averse subjects chose the tournament compensation. Subjects classified as behindness averse are significantly less likely to choose the competitive wage scheme ( $\mathrm{p}$-value $<0.001)$. There is no significant difference in the choice of the tournament wage scheme between those who prefer favorable inequality and those who do not $(\mathrm{p}$-value $=0.43)$. 
[Figure 2 here]

In Figure 2 we also present disaggregated results by gender. We find that there is no statistically significant difference between egalitarian males' and females' choices of the tournament wage scheme (p-value $=0.25)$. Further, males exhibiting a preference for favorable inequality as well as behindness aversion choose the tournament wage scheme more often than females characterized by the same distributional preferences. These differences are statistically significant at the 1 percent level.

Our sample has almost equal representation of males and females. Fifty-eight percent of subjects belong to families with a high income (defined as those with monthly income of at least Rs. 50,000) and 53 percent of our subjects have highly educated parents where both the mother and father have completed at least a college degree. Female subjects are significantly more likely to have well educated parents as well as belong to families with more income ( $\mathrm{p}$-value $<0.001)$.

[Table 2 here]

The average score on the Raven's test is 6.50, and females have a significantly higher score than males ( $\mathrm{p}$-value $=0.0126$ ). Using our measure of confidence, we find one-third of students appear confident. Males are significantly more confident than females (p-value < 0.001). Females in our sample are significantly more risk-averse than males ( $\mathrm{p}$-value < 0.001 ) as typically exhibited in the investment task (Charness and Gneezy, 2012). The summary statistics on personality traits indicate that females score significantly higher on traits of extraversion (p-value $<0.001$ ), agreeableness (pvalue $<0.001$ ), and conscientiousness ( $\mathrm{p}$-value $<0.001$ ) and significantly lower on emotional stability ( $\mathrm{p}$-values < 0.001) and locus of control ( $\mathrm{p}$-value $=0.054)$. These gender differences in personality traits are in line with the literature (Feingold, 1994; Costa, Terracciano and McCrae, 2001). Overall, Table 2 indicates significant gender differences in willingness to compete as well as in most RHS characteristics. ${ }^{7}$

\footnotetext{
${ }^{7}$ Sample means on risk preference and competitiveness obtained from our incentivized tasks are also consistent with risk and competitiveness averages previously obtained from a different sample in India (Dasgupta et al., 2015).
} 


\subsection{Regression Analysis}

We start by describing the models we propose to estimate in our analysis. To be consistent with the previous literature, we start by estimating the following two equations:

$$
\begin{gathered}
\text { Compete }_{\mathrm{i}}=\beta_{0}+\beta_{1} \text { Female }_{\mathrm{i}}+\varepsilon_{\mathrm{i}} \\
\text { Compete }_{\mathrm{i}}=\beta_{0}+\beta_{1} \text { Female }_{\mathrm{i}}+\beta_{2} \text { Favorable inequality }_{\mathrm{i}}+\beta_{3} \text { Behindness averse }_{\mathrm{i}} \\
+\sum_{\mathrm{j}=4}^{\mathrm{N}} \beta_{\mathrm{j}} \mathrm{X}_{\mathrm{ij}}+\varepsilon_{\mathrm{i}}
\end{gathered}
$$

where, Compete takes a value 1 if the individual chooses the tournament wage scheme, 0 if piece rate. Female takes a value 1 if subject is female, 0 if male. Vector $X$ includes the full set of socioeconomic characteristics, behavioral, and personality traits that influence entry into competition and have been described in Section 2 and summarized in Table 2. Equation (1) above captures the unconditional gender gap in competitiveness while equation (2) controls for the variations in distributional preferences (namely preference for favorable inequality, and dispreference for unfavorable inequality/behindness averse choices) as well as variables included in vector $X$ to provide a conditional effect of gender on competitiveness. Further, since our primary interest is in determining whether ceteris paribus, gendered differences in distributional preferences influence entry into tournament compensation scheme, we estimate equation (3) where we control for gendered differences in distributional preferences using interaction terms between the female dummy and distributional preferences (female*favorable inequality, female*behindness averse). To examine whether gender gaps in competitiveness are explained by gendered differences in family background, behavior and personality traits, we also include a full set of interaction terms between each variable in vector $X$ and the female dummy in equation (3) below.

$$
\begin{gathered}
\text { Compete }_{\mathrm{i}}=\beta_{0}+\beta_{1} \text { Female }_{\mathrm{i}}+\beta_{2} \text { Favorable inequality }_{\mathrm{i}}+\beta_{3} \text { Behindness averse }_{\mathrm{i}}+ \\
\begin{array}{c}
\sum_{\mathrm{j}=4}^{\mathrm{N}} \beta_{\mathrm{j}} \mathrm{X}_{\mathrm{ij}}+\delta_{1}(\text { Female } * \text { Favorable inequality })_{\mathrm{i}}+\delta_{2}(\text { Female } * \text { Behindness averse })_{\mathrm{i}}+ \\
\sum_{\mathrm{j}=3}^{\mathrm{N}} \delta_{\mathrm{j}}(\text { Female } * \mathrm{X})_{\mathrm{ij}}+\varepsilon_{\mathrm{i}}
\end{array}
\end{gathered}
$$

In estimating the above equations, we use linear probability models instead of the probit fixed effect estimators since the latter suffers from the incidental parameter problem (Greene, 2004). We also 
control for session and gender-session fixed effects which allow us to: (a) account for all session and gender-session level unobservables; and (b) address cluster related unobservables in standard errors since common session-level unobservables are also cluster effects (Wooldridge, 2003). ${ }^{8}$

[Table 3 here]

Regression results are reported in Table 3. Column 1 describes the unconditional gender gap in the willingness to compete (equation 1). We find that females are 15.6 percentage points less likely than males to choose the competition wage scheme. In Column 2, we estimate a variant of equation (2), where we account for distributional preferences with an egalitarian dummy. In this specification, we also control for confidence, risk preferences, task-related ability, general cognitive ability (Raven's test score), standardized measures of Big Five and locus of control personality traits, family income, and parental education. We find that even after controlling for egalitarian preferences and a host of socioeconomic characteristics and personality traits, the coefficient estimate on the female dummy remains similar to Column 1 and shows that females are 14 percentage points less likely to choose the tournament wage scheme. As expected, being egalitarian is negatively associated with competitiveness. In Column 3, we estimate equation (2) where we now disaggregate distributional preferences into preferences over favorable and unfavorable inequalities instead of egalitarian preferences. As hypothesized earlier, our results indicate an asymmetric relationship in that the subjects who prefer favorable inequality are 5 percentage points more likely to choose the tournament wage scheme, whereas behindness averse subjects are 6 percentage points less likely to select into the tournament wage scheme. The difference in the magnitude of these effects is statistically significant ( $\mathrm{p}$-value $<0.001$ ). We find that subjects' confidence positively influences selection into tournaments and risk attitudes also influence entry in the expected direction, i.e., subjects with lower risk aversion enter tournaments more often. This is an intuitively obvious result since opting into the tournament scheme exposes the decision-maker to the possibility of zero payoffs. Socioeconomic characteristics such as parents' education and family income seem to have negligible and insignificant effects on entry into competitive situations in our context.

Our results on the personality traits indicate that subjects scoring higher on the Big Five trait of openness to experience, and those with a greater or more internalized locus of control are more likely to enter into the tournament wage scheme. This suggests that subjects who believe that they

\footnotetext{
${ }^{8}$ All regressions have been estimated using regress command in STATA15. In addition, our results are robust to estimations using probit models (dprobit command).
} 
are in charge of their own actions and fate, rather than those who believe that some outside force mediates their life, are more willing to compete. In Columns 2 and 3, in addition, we find all controls to be jointly significant. ${ }^{9}$

From the results in Columns 2 and 3 in Table 3, we observe that even with the inclusion of a large set of covariates over and above those identified in the previous literature, the coefficient on the female dummy remains sizable and significantly different from zero. We find females to be 13-14 percentage points less willing to compete than males. ${ }^{10}$ Consequently, our results based on the predominantly used empirical specifications in the literature suggest that females are significantly less willing to compete compared to males, though the source of this gender difference is not examined. This observation changes however, in what follows next.

Columns 1-3 of Table 3 do not allow for the influence of RHS characteristics to vary by gender. As explained earlier, such a variation could also explain differences in willingness to compete between males and females. Such heterogeneity assumes considerable importance in the context of a developing country where differential investments in females begin early on and returns to the same level of endowments typically vary between males and females. To address this issue, we estimate equation (3) and its variants in Columns 4-5 of Table 3 where we control for the genderdifferentiated effects by interacting the female dummy with all the RHS characteristics.

In Column 4, we examine the gender-differentiated effects of egalitarian preferences on competition, controlling for gendered-differences in all other covariates. We find that females with a preference for being egalitarian are 10 percentage points more likely to compete than egalitarian males. In Column 5, in examining the gender-differentiated effect of preference for favorable inequality and behindness aversion, we find that females who prefer favorable inequality are 9 percentage points less likely to choose the tournament wage scheme compared to males who prefer favorable inequality but this result is not significant at conventional levels ( $p$-value $=0.11$ ). In

\footnotetext{
${ }^{9}$ We also examine pair-wise correlation coefficients between the different socioeconomic characteristics, behavioral characteristics, and personality traits included in the regression analysis. The highest correlation between any pair of RHS variables is 0.41 ruling out multicollinearity related concerns.

10 The results remain mixed on this issue. While Datta Gupta, Poulsen and Villeval (2013) and Niederle and Vesterlund (2007) find gender gaps in competitiveness to persist even upon inclusion of a host of controls, Balafoutas et al. (2012) and Kamas and Preston (2015) find the gender gap to disappear. It is important to point out here that these papers do not use the same set of RHS characteristics.
} 
contrast, behindness averse females are 12.7 percentage points more likely to choose the tournament wage scheme compared to males with behindness averse preferences. Overall, we find significant gender differences in the impact of distributional preferences such as egalitarian choices and behindness averse choices on competition explaining some of the sources of gender gaps noted in Column 1-3, Table 3.

We also find the relationship between the Big Five traits of conscientiousness and emotional stability and competition to vary by gender. In Column 5, in comparison to males, conscientious females are 4 percentage points more likely to enter the tournament wage scheme. However, in comparison to males, emotionally stable females are 4 percentage points less likely to select the tournament wage scheme. In contrast, the other interaction terms are not statistically significant. In Columns 4 and 5, we find all RHS characteristics as well as their interactions with the female dummy to be jointly significant (see associated F-test results reported in Table 3). A comparison of adjusted R-squared across columns also shows an increase indicating that the addition of controls in Columns 4 and 5 is meaningful and explains additional variation in the willingness to compete. Importantly, the coefficient estimates on the interaction terms (female dummy and RHS characteristics) in Columns 4 and 5 are statistically significant highlighting the gendered differences prevalent in behavior and personality traits, that help explain the source of gender gaps in competitiveness noted in Columns $1-3$, Table $3 .{ }^{11}$

\section{[Table 4 here]}

Our results above lead us to comment on and understand further the relative contributions of the different interaction terms in explaining gender gaps in competitiveness as we control for an exhaustive set of controls in comparison to previous literature. To do so, we standardize the full vector of RHS characteristics with respect to sample means and standard deviations. In Table 4, we estimate regressions like those in Columns 4 and 5 in Table 3. The coefficients now correspond to standardized effect sizes and can be interpreted as relative importance of one factor vis-à-vis others. In Columns 1 and 2 of Table 4, assessing the coefficients on the gender-interacted variables, we see that the most economically and statistically significant terms explaining gender gaps in entry into competitive situations are gender differences in distributional preferences (egalitarian preferences

\footnotetext{
${ }^{11}$ Note that the results reported in Table 3 are robust to including fewer controls. These additional results are available upon request.
} 
and behindness aversion), and gender differences in traits of conscientiousness and emotional stability. Gender gaps in family background and other behavioral and personality factors are not statistically significant and have smaller magnitudes. This suggests that the observed gender difference in competitiveness can be driven primarily by male-female differences in distributional preferences and selected personality traits developed through one's lifetime.

\section{Conclusion}

We ran an experiment to analyze the relationship between distributional preferences and competitiveness in India with approximately 2,000 college students. Our objective was twofold: the first was to examine if a preference for favorable inequality and behindness aversion affects selection into competitive environment; the second was to test whether gender differences in such distributional preferences explain gender gaps in competitiveness, after allowing for the effects of all standard controls to also vary by gender. The latter point is of particular interest in a developing country setting where in the presence of differential treatment of girls compared to boys, one may expect the numerous characteristics to differentially affect willingness to compete based on gender.

In our baseline specification used as in the existing literature, albeit with a rich set of controls, we find that females are significantly less likely to enter competitive situations than males, and further, selection into competitive environments is negatively related to egalitarian preferences, with smaller negative effect of being egalitarian on females' choice of the tournament wage scheme. Once we classify subjects according to preference for favorable inequality and behindness aversion, choice to compete appear to be negatively affected by behindness averse choices, while preference for favorable inequality positively influences the choice of the tournament wage scheme. Next, examining gender differences in these distributional preferences we find that compared to behindness averse males, behindness averse females are 13 percentage points more likely to enter the tournament wage scheme. In contrast, we do not find any significant gender difference in the relationship between preference for favorable inequality and competition. We conclude that (a) preferences for favorable inequality and behindness averse choices influence competitive choices differently, and (b) indeed gender differences in distributional preferences explain observed variations in competitiveness. Finally, standardized regressions show that gender differences in distributional preferences and personality traits relating to conscientiousness and emotional stability 
appear to be the most economically relevant predictors of gender gaps in competitive choices. Overall, our results suggest that the observed gender difference in competitiveness may be driven by male-female differences in distributional preferences and selected personality traits developed during one's lifetime. 


\section{References}

Andersen, S., Ertac, S., Gneezy, U., List, J.A., and Maximiano, S. (2013). Gender, Competitiveness, and Socialization at a Young Age: Evidence from a Matrilineal and a Patriarchal Society. Review of Economics and Statistics, 95(4), 1438-1443.

Andreoni, J., and Vesterlund, L. (2001). Which is the fair sex? Quarterly Journal of Economics, 116(1), 293-312.

Balafoutas, L., Kerschbamer, R., and Sutter, M. (2012). Distributional preferences and competitive behavior. Journal of Economic Behavior and Organization, 83, 125-135.

Barry, E (2016, January 30). In India, a Small Band of Women Risk It All for a Chance to Work. New York Times. https://www.nytimes.com/2016/01/31/world/asia/indian-women-labor-workforce.html (accessed in January 2017)

Bartling, B., Fehr, E., Maréchal, M.A., and Schunk, D. (2009). Egalitarianism and Competitiveness. American Economic Review: Papers \& Proceedings, 99(2), 93-98.

Bauer, M., Chytilova, J., and Pertold-Gebicka, B. (2014). Parental background and otherregarding preferences in children. Experimental Economics, 17, 24-46.

Beranek, B., Cubitt, R., and Gächter, S. (2015). Stated and revealed inequality aversion in three subject pools. Journal of Economic Science Association, 1, 43-58.

Buser, T., Niederle, M., and Oosterbeek, H. (2014). Gender, Competitiveness and Career Choices. Quarterly Journal of Economics, 129(3), 1409-1447.

Caliendo M., Fossen F., and Kritikos, A. (2014) Personality characteristics and the decision to become and stay self-employed. Small Business Economics, 42(4), 787-814.

Charness, G., and Gneezy, U. (2012). Strong Evidence for Gender Differences in Risk Taking. Journal of Economic Behavior and Organization, 83, 50-58.

Cobb-Clark, D.A., and Tan, M. (2011). Non-cognitive skills, occupational attainment, and relative wages. Labour Economics, 18(1), 1-13.

Costa, P.T., Terracciano, A., and McCrae, R.R. (2001). Gender differences in personality traits across cultures: robust and surprising findings. Journal of Personality and Social Psychology, 81(2), 322-331. 
Cubel, M., Nuevo-Chiquero, A., Sanchez-Pages, S., and Vidal-Fernandez, M. (2016). Do personality traits affect productivity? Evidence from the laboratory. Economic Journal, 126(592), 654-681.

Croson, R., and Gneezy, U. (2009). Gender Differences in Preferences. Journal of Economic Literature, 47(2), 448-474.

Dasgupta, U., Gangadharan, L., Maitra, P., Mani, S., \& Subramanian, S. (2015). Choosing to be trained: Do behavioral traits matter? Journal of Economic Behavior \& Organization, 110, 145-159.

Dufwenberg, M., and Muren, A. (2006). Generosity, anonymity and gender. Journal of Economic Behavior and Organization, 61, 42-49.

Datta Gupta, N., Poulsen, A., and Villeval, M.C. (2013). Gender matching and competitiveness: experimental evidence. Economic Inquiry, 51(1), 816-835.

Engel, C. (2011). Dictator games: a meta study. Experimental Economics, 14, 583-610.

Fehr, E., Bernhard, H., and Rockenbach, B. (2008). Egalitarianism in young children. Nature, 454, 1079-1084.

Fehr, E., and Schmidt, K.M. (1999). A Theory of Fairness, Competition, and Cooperation, Quarterly Journal of Economics, 114 (3), 817-868.

Feingold, A. (1994). Gender differences in personality: a meta-analysis. Psychological Bulletin, 116(3), 429-456.

Flory, J.A., Leibbrandt, A., and List, J.A. (2015). Do competitive work places deter female workers? A large-scale natural field experiment on job entry decisions. Review of Economic Studies, 82(1), 122-155.

Frank, R. (1996). The Winner-Take-All Society: Why the Few at the Top Get So Much More Than the Rest of Us. Penguin Books: New York.

Gill, D., and Prowse, V. (2014). Gender differences and dynamics in competition: the role of luck. Quantitative Economics, 5, 351-376.

Gill, D., and Prowse, V. (2016). Cognitive ability, character skills, and learning to play equilibrium: A level-k analysis. Journal of Political Economy, 126(4), 1619-1676. 
Gneezy, U., and Potters, J. (1997). An experiment on risk taking and evaluation periods. Quarterly Journal of Economics, 112(2), 631-645.

Gosling, S.D., Rentfrow, P.J., and Swann Jr., W.B. (2003). A very brief measure of the Big-Five personality domains. Journal of Research in Personality, 37, 504-528.

Greene, W. (2004). The Behaviour of the Maximum Likelihood Estimator of Limited Dependent Variable Models in the Presence of Fixed Effects. The Econometrics Journal, 7, 98-119.

Jayachandran, S. (2015). The roots of gender inequality in developing countries. Annual Review of Economics, 7, 63-88.

Kamas, L., and Preston, A. (2015). Can social preferences explain gender differences in economic behavior? Journal of Economic Behavior \& Organization, 116, 525-539.

Mueller, S.L., and Thomas, A.S. (2000). Culture and entrepreneurial potential: a nine-country study of locus of control and innovativeness. Journal of Business Venturing, 16, 51-75.

Müller, J., and Schwieren, C. (2012). Can personality explain what is underlying women's unwillingness to compete? Journal of Economic Psychology, 33, 448-460.

Niederle, M., and Vesterlund, L. (2007). Do Women Shy Away from Competition? Do Men Compete to Much? Quarterly Journal of Economics, 122(3), 1067-1101.

Niederle, M., and Vesterlund, L. (2011). Gender and Competition, Annual Review of Economics, 3, 601-630.

Niederle, M. (2016). Gender, Handbook in Experimental Economics, second edition, Eds. John H. Kagel and Alvin E. Roth, Princeton University Press, 481-553.

Rotter, J.B. (1966). Generalized expectancies for internal versus external control of reinforcement. Psychological Monographs: General and Applied, 80(1), 1-28.

Sharma, S. (2015). Gender and distributional preferences: experimental evidence from India. Journal of Economic Psychology, 50, 113-123.

Teyssier, S. (2008). Experimental Evidence on Inequity Aversion and Self-Selection between Incentive Contracts. Working paper GATE 08-21.

Wooldridge, J. M. (2003). Cluster-sample Methods in Applied Econometrics. American Economic Review, 93, 133-138. 
Wooldridge, J. M. (2006). Introductory econometrics: A modern approach. Mason, OH: Thomas/South-Western. 


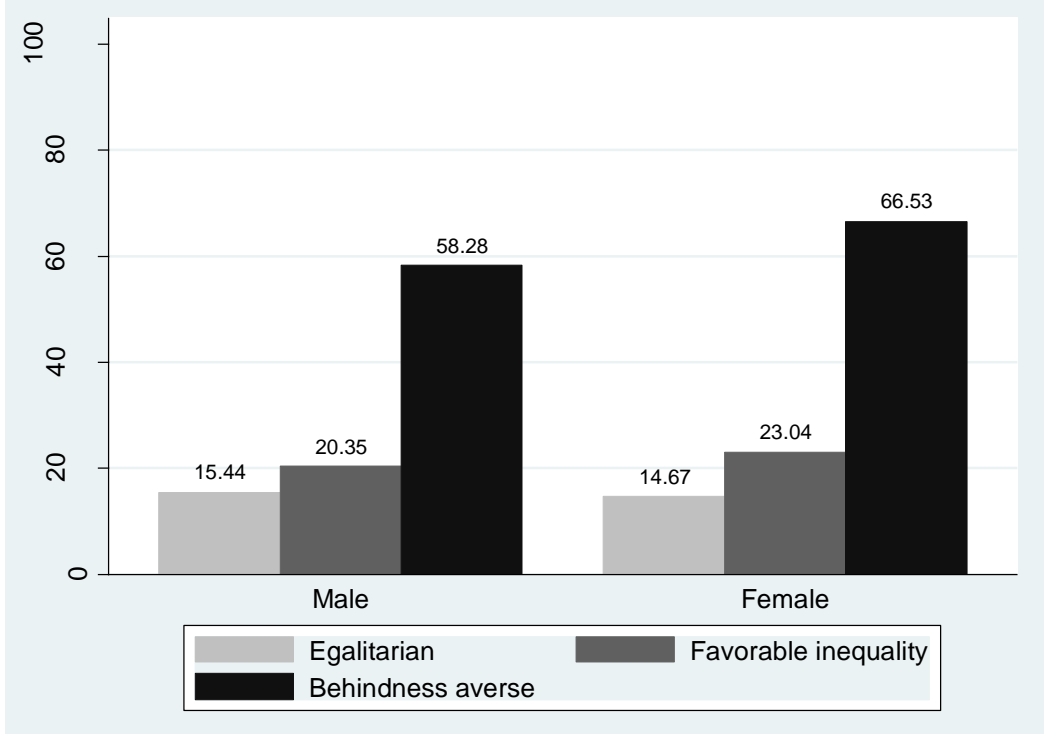

Figure 1: Distributional Preferences, by Gender 


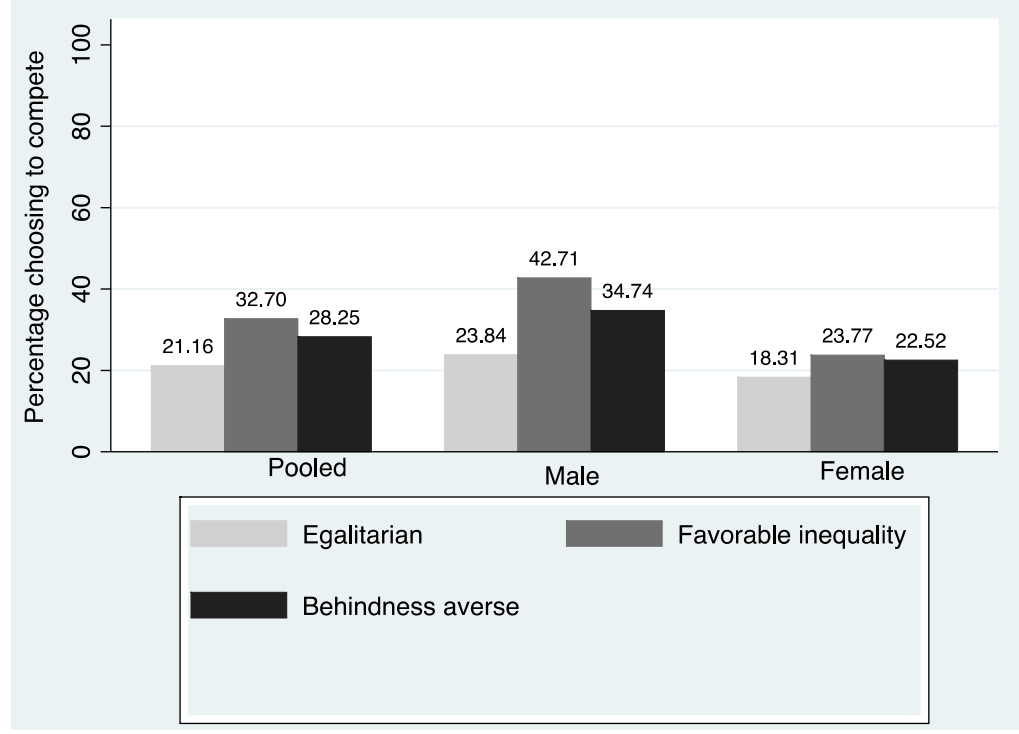

Figure 2: Willingness to Compete based on Distributional Preferences 


\section{Table 1: Distribution game}

\begin{tabular}{|c|c|c|c|}
\hline & Option A & & Option B \\
\hline Row 1 & $\begin{array}{c}\text { You get Rs. 200; and } \\
\text { Other person gets Rs. } \\
200 .\end{array}$ & OR & $\begin{array}{c}\text { You get Rs. 200; and } \\
\text { Other person gets Rs. } \\
120 .\end{array}$ \\
\hline Row 2 & $\begin{array}{c}\text { You get Rs. 200; and } \\
\text { Other person gets Rs. } \\
200 .\end{array}$ & OR & $\begin{array}{l}\text { You get Rs. 320; and } \\
\text { Other person gets Rs. } \\
80 .\end{array}$ \\
\hline Row 3 & $\begin{array}{c}\text { You get Rs. 200; } \\
\text { Other person gets Rs. } \\
200 .\end{array}$ & OR & $\begin{array}{c}\text { You get Rs. 200; and } \\
\text { Other person gets Rs. } \\
360 .\end{array}$ \\
\hline Row 4 & $\begin{array}{c}\text { You get Rs. 200; } \\
\text { Other person gets Rs. } \\
200 .\end{array}$ & OR & $\begin{array}{l}\text { You get Rs. 220; and } \\
\text { Other person gets Rs. } \\
\quad 380 .\end{array}$ \\
\hline
\end{tabular}


Table 2: Summary statistics

\begin{tabular}{|c|c|c|c|c|}
\hline Variable & $\begin{array}{c}(1) \\
\text { Pooled }\end{array}$ & $\begin{array}{c}(2) \\
\text { Male }\end{array}$ & $\begin{array}{c}\text { (3) } \\
\text { Female }\end{array}$ & $\begin{array}{c}(4) \\
\text { Male-female } \\
\text { gap } \\
\text { p-values }\end{array}$ \\
\hline Female & $\begin{array}{l}0.498 \\
(0.50)\end{array}$ & & & \\
\hline Compete & $\begin{array}{c}0.31 \\
(0.46)\end{array}$ & $\begin{array}{c}0.39 \\
(0.49)\end{array}$ & $\begin{array}{c}0.23 \\
(0.42)\end{array}$ & $<0.001$ \\
\hline Egalitarian & $\begin{array}{c}0.15 \\
(0.36)\end{array}$ & $\begin{array}{l}0.154 \\
(0.36)\end{array}$ & $\begin{array}{l}0.147 \\
(0.35)\end{array}$ & 0.63 \\
\hline Favorable inequality & $\begin{array}{c}0.22 \\
(0.41)\end{array}$ & $\begin{array}{c}0.20 \\
(0.40)\end{array}$ & $\begin{array}{c}0.23 \\
(0.42)\end{array}$ & 0.15 \\
\hline Behindness averse & $\begin{array}{c}0.62 \\
(0.48)\end{array}$ & $\begin{array}{c}0.58 \\
(0.49)\end{array}$ & $\begin{array}{c}0.67 \\
(0.47)\end{array}$ & $<0.001$ \\
\hline Risk preference (\% invested) & $\begin{array}{c}46.83 \\
(18.89)\end{array}$ & $\begin{array}{c}49.83 \\
(21.26)\end{array}$ & $\begin{array}{c}43.8 \\
(15.59)\end{array}$ & $<0.001$ \\
\hline Ability & $\begin{array}{c}2.32 \\
(0.89)\end{array}$ & $\begin{array}{c}2.30 \\
(0.90)\end{array}$ & $\begin{array}{c}2.35 \\
(0.88)\end{array}$ & 0.23 \\
\hline Confidence & $\begin{array}{c}0.32 \\
(0.46)\end{array}$ & $\begin{array}{c}0.36 \\
(0.48)\end{array}$ & $\begin{array}{c}0.27 \\
(0.45)\end{array}$ & $<0.001$ \\
\hline Raven's test score & $\begin{array}{c}6.50 \\
(2.26)\end{array}$ & $\begin{array}{c}6.37 \\
(2.36)\end{array}$ & $\begin{array}{c}6.63 \\
(2.15)\end{array}$ & 0.0126 \\
\hline Parents' education & $\begin{array}{c}0.53 \\
(0.50)\end{array}$ & $\begin{array}{c}0.42 \\
(0.49)\end{array}$ & $\begin{array}{c}0.63 \\
(0.48)\end{array}$ & $<0.001$ \\
\hline Family income & $\begin{array}{c}0.58 \\
(0.49)\end{array}$ & $\begin{array}{c}0.54 \\
(0.50)\end{array}$ & $\begin{array}{c}0.63 \\
(0.48)\end{array}$ & $<0.001$ \\
\hline Openness to experience & $\begin{array}{c}5.35 \\
(1.13)\end{array}$ & $\begin{array}{c}5.32 \\
(1.14)\end{array}$ & $\begin{array}{c}5.37 \\
(1.12)\end{array}$ & 0.348 \\
\hline Conscientiousness & $\begin{array}{c}5.28 \\
(1.26)\end{array}$ & $\begin{array}{c}5.20 \\
(1.27)\end{array}$ & $\begin{array}{c}5.36 \\
(1.25)\end{array}$ & 0.004 \\
\hline Emotional stability & $\begin{array}{c}4.56 \\
(1.33)\end{array}$ & $\begin{array}{c}4.70 \\
(1.29)\end{array}$ & $\begin{array}{c}4.42 \\
(1.35)\end{array}$ & $<0.001$ \\
\hline Agreeableness & $\begin{array}{c}5.11 \\
(1.15)\end{array}$ & $\begin{array}{c}4.93 \\
(1.17)\end{array}$ & $\begin{array}{c}5.30 \\
(1.12)\end{array}$ & $<0.001$ \\
\hline Extraversion & $\begin{array}{c}4.61 \\
(1.39)\end{array}$ & $\begin{array}{c}4.49 \\
(1.34)\end{array}$ & $\begin{array}{c}4.74 \\
(1.42)\end{array}$ & $<0.001$ \\
\hline Locus of control & $\begin{array}{c}7.27 \\
(1.96)\end{array}$ & $\begin{array}{c}7.36 \\
(1.95)\end{array}$ & $\begin{array}{c}7.19 \\
(1.97)\end{array}$ & 0.054 \\
\hline Sample size & 1946 & 978 & 968 & \\
\hline
\end{tabular}

Notes: Columns 1, 2, and 3 report sample means along with standard deviations in parentheses. In Column 4, we report two-sided p-values from a simple proportions test (for dichotomous variables only) or t-test (all other variables). For openness to experience, conscientiousness, emotional stability, agreeableness, and extraversion, the maximum score is 7. For locus of control, the maximum score is 13 . For Raven's test, the maximum score is 10. 'Family income' takes a value 1 if monthly income is at least Rs. 50,000. 'Parents' education' takes a value 1 where both the mother and father have completed at least a college degree. 
Table 3: Gender differences in willingness to compete

\begin{tabular}{|c|c|c|c|c|c|}
\hline & $\begin{array}{c}(1) \\
\text { Compete }\end{array}$ & $\begin{array}{c}(2) \\
\text { Compete }\end{array}$ & $\begin{array}{c}(3) \\
\text { Compete }\end{array}$ & $\begin{array}{c}(4) \\
\text { Compete }\end{array}$ & $\begin{array}{c}(5) \\
\text { Compete }\end{array}$ \\
\hline Female & $\begin{array}{c}-0.156 * * * \\
(0.021)\end{array}$ & $\begin{array}{c}-0.143 * * * \\
(0.022)\end{array}$ & $\begin{array}{c}-0.138 * * * \\
(0.022)\end{array}$ & $\begin{array}{l}-0.071 \\
(0.106)\end{array}$ & $\begin{array}{l}-0.099 \\
(0.108)\end{array}$ \\
\hline Egalitarian & & $\begin{array}{c}-0.093 * * * \\
(0.027)\end{array}$ & & $\begin{array}{c}-0.153 * * * \\
(0.043)\end{array}$ & \\
\hline Female*egalitarian & & & & $\begin{array}{l}0.104 * \\
(0.056)\end{array}$ & \\
\hline Favorable inequality & & & $\begin{array}{l}0.050^{*} \\
(0.027)\end{array}$ & & $\begin{array}{c}0.101 * * \\
(0.044)\end{array}$ \\
\hline Behindness averse & & & $\begin{array}{c}-0.062 * * * \\
(0.023)\end{array}$ & & $\begin{array}{c}-0.126 * * * \\
(0.035)\end{array}$ \\
\hline $\begin{array}{l}\text { Female*favorable } \\
\text { inequality }\end{array}$ & & & & & $\begin{array}{l}-0.089 \\
(0.056)\end{array}$ \\
\hline Female*behindness averse & & & & & $\begin{array}{c}0.127 * * * \\
(0.047)\end{array}$ \\
\hline Risk preference & & $\begin{array}{c}0.001 * * \\
(0.001)\end{array}$ & $\begin{array}{c}0.001 * * * \\
(0.001)\end{array}$ & $\begin{array}{c}0.001 \\
(0.001)\end{array}$ & $\begin{array}{c}0.001 \\
(0.001)\end{array}$ \\
\hline Confidence & & $\begin{array}{c}0.082 * * * \\
(0.023)\end{array}$ & $\begin{array}{c}0.081 * * * \\
(0.023)\end{array}$ & $\begin{array}{l}0.070 * * \\
(0.034)\end{array}$ & $\begin{array}{l}0.074 * * \\
(0.033)\end{array}$ \\
\hline Ability & & $\begin{array}{l}0.020 * \\
(0.011)\end{array}$ & $\begin{array}{l}0.020^{*} \\
(0.011)\end{array}$ & $\begin{array}{c}0.029 \\
(0.018)\end{array}$ & $\begin{array}{c}0.028 \\
(0.018)\end{array}$ \\
\hline Raven's test score & & $\begin{array}{c}0.003 \\
(0.011)\end{array}$ & $\begin{array}{c}0.002 \\
(0.011)\end{array}$ & $\begin{array}{c}0.014 \\
(0.016)\end{array}$ & $\begin{array}{c}0.012 \\
(0.016)\end{array}$ \\
\hline Extraversion & & $\begin{array}{c}0.011 \\
(0.010)\end{array}$ & $\begin{array}{c}0.010 \\
(0.010)\end{array}$ & $\begin{array}{c}0.013 \\
(0.016)\end{array}$ & $\begin{array}{c}0.013 \\
(0.016)\end{array}$ \\
\hline Agreeableness & & $\begin{array}{l}-0.005 \\
(0.011)\end{array}$ & $\begin{array}{l}-0.005 \\
(0.011)\end{array}$ & $\begin{array}{l}-0.015 \\
(0.016)\end{array}$ & $\begin{array}{l}-0.013 \\
(0.016)\end{array}$ \\
\hline Conscientiousness & & $\begin{array}{l}-0.006 \\
(0.011)\end{array}$ & $\begin{array}{l}-0.006 \\
(0.011)\end{array}$ & $\begin{array}{l}-0.024 \\
(0.017)\end{array}$ & $\begin{array}{l}-0.026 \\
(0.016)\end{array}$ \\
\hline Emotional stability & & $\begin{array}{c}0.009 \\
(0.010)\end{array}$ & $\begin{array}{c}0.009 \\
(0.010)\end{array}$ & $\begin{array}{l}0.034 * * \\
(0.017)\end{array}$ & $\begin{array}{c}0.033 * * \\
(0.017)\end{array}$ \\
\hline Openness to experience & & $\begin{array}{l}0.020 * \\
(0.011)\end{array}$ & $\begin{array}{c}0.021 * * \\
(0.011)\end{array}$ & $\begin{array}{c}0.024 \\
(0.016)\end{array}$ & $\begin{array}{c}0.023 \\
(0.016)\end{array}$ \\
\hline Locus of control & & $\begin{array}{l}0.019 * \\
(0.010)\end{array}$ & $\begin{array}{l}0.019^{*} \\
(0.010)\end{array}$ & $\begin{array}{c}0.022 \\
(0.016)\end{array}$ & $\begin{array}{c}0.023 \\
(0.016)\end{array}$ \\
\hline Family income & & $\begin{array}{c}0.029 \\
(0.023)\end{array}$ & $\begin{array}{c}0.030 \\
(0.023)\end{array}$ & $\begin{array}{c}0.010 \\
(0.035)\end{array}$ & $\begin{array}{c}0.009 \\
(0.035)\end{array}$ \\
\hline Parents' education & & $\begin{array}{c}0.018 \\
(0.023)\end{array}$ & $\begin{array}{c}0.018 \\
(0.023)\end{array}$ & $\begin{array}{c}0.009 \\
(0.037)\end{array}$ & $\begin{array}{c}0.008 \\
(0.037)\end{array}$ \\
\hline Female*risk preference & & & & $\begin{array}{c}0.001 \\
(0.001)\end{array}$ & $\begin{array}{c}0.001 \\
(0.001)\end{array}$ \\
\hline Female*confidence & & & & $\begin{array}{c}0.017 \\
(0.047)\end{array}$ & $\begin{array}{c}0.012 \\
(0.047)\end{array}$ \\
\hline Female*ability & & & & $\begin{array}{c}-0.016 \\
(0.023)\end{array}$ & $\begin{array}{c}-0.016 \\
(0.023)\end{array}$ \\
\hline $\begin{array}{l}\text { Female*raven's test } \\
\text { score }\end{array}$ & & & & $\begin{array}{l}-0.026 \\
(0.022)\end{array}$ & $\begin{array}{l}-0.023 \\
(0.022)\end{array}$ \\
\hline Female*extraversion & & & & $\begin{array}{c}0.004 \\
(0.021)\end{array}$ & $\begin{array}{c}0.004 \\
(0.021)\end{array}$ \\
\hline $\begin{array}{l}\text { Female*agreeableness to } \\
\text { experience }\end{array}$ & & & & $\begin{array}{c}0.025 \\
(0.022)\end{array}$ & $\begin{array}{c}0.023 \\
(0.022)\end{array}$ \\
\hline Female*conscientiousness & & & & $\begin{array}{l}0.042 * \\
(0.022)\end{array}$ & $\begin{array}{c}0.044 * * \\
(0.022)\end{array}$ \\
\hline Female*emotional stability & & & & $\begin{array}{c}-0.048 * * \\
(0.021)\end{array}$ & $\begin{array}{c}-0.046 * * \\
(0.021)\end{array}$ \\
\hline
\end{tabular}


Female*openness to

experience

\begin{tabular}{ccccc} 
& & & -0.011 & -0.008 \\
& & & $(0.022)$ & $(0.022)$ \\
& & & -0.010 & -0.009 \\
& & & $(0.021)$ & $(0.021)$ \\
& & & 0.021 & 0.022 \\
& & & $(0.046)$ & $(0.046)$ \\
$0.086^{* * *}$ & -0.058 & -0.057 & -0.094 & -0.083 \\
$(0.019)$ & $(0.054)$ & $(0.055)$ & $(0.085)$ & $(0.085)$ \\
& 5.16 & 4.23 & 3.04 & 2.72 \\
& & & & \\
& $(<0.001)$ & $(<0.001)$ & $(<0.001)$ & $(<0.001)$ \\
\hline Yes & 1.98 & 1.97 & 1.55 & 1.56 \\
No & Yes & Yes & Yes & Yes \\
1946 & 1946 & 1946 & 1946 & 1946 \\
0.098 & 0.126 & 0.125 & 0.175 & 0.175 \\
\hline
\end{tabular}

Female*family income

Female*parents' education

Constant

0.126

0.125

0.175

0.175

Notes: $* * * \mathrm{p}<0.01, * * \mathrm{p}<0.05$ and $* \mathrm{p}<0.10$. Robust standard errors in parentheses. See notes of Table 2 for variable definitions. 
Table 4: Gender differences in willingness to compete: Results from standardized regressions

\begin{tabular}{|c|c|c|}
\hline & $\begin{array}{c}(1) \\
\text { Compete }\end{array}$ & $\begin{array}{c}(2) \\
\text { Compete }\end{array}$ \\
\hline Female & $\begin{array}{l}-0.035 \\
(0.053)\end{array}$ & $\begin{array}{c}-0.050 \\
(0.054)\end{array}$ \\
\hline Egalitarian & $\begin{array}{c}-0.055^{* * *} \\
(0.015)\end{array}$ & \\
\hline Female*egalitarian & $\begin{array}{l}0.027 * \\
(0.015)\end{array}$ & \\
\hline Favorable inequality & & $\begin{array}{c}0.042 * * \\
(0.018)\end{array}$ \\
\hline Behindness averse & & $\begin{array}{c}-0.061 * * * \\
(0.017)\end{array}$ \\
\hline Female*favorable inequality & & $\begin{array}{c}-0.028 \\
(0.018)\end{array}$ \\
\hline Female*behindness averse & & $\begin{array}{c}0.060 * * * \\
(0.022)\end{array}$ \\
\hline Risk preference & $\begin{array}{c}0.020 \\
(0.014)\end{array}$ & $\begin{array}{c}0.021 \\
(0.014)\end{array}$ \\
\hline Confidence & $\begin{array}{c}0.033 * * \\
(0.016)\end{array}$ & $\begin{array}{c}0.034 * * \\
(0.016)\end{array}$ \\
\hline Ability & $\begin{array}{c}0.026 \\
(0.016)\end{array}$ & $\begin{array}{c}0.026 \\
(0.016)\end{array}$ \\
\hline Raven's test score & $\begin{array}{c}0.014 \\
(0.016)\end{array}$ & $\begin{array}{c}0.012 \\
(0.016)\end{array}$ \\
\hline Extraversion & $\begin{array}{c}0.013 \\
(0.016)\end{array}$ & $\begin{array}{c}0.013 \\
(0.016)\end{array}$ \\
\hline Agreeableness & $\begin{array}{c}-0.015 \\
(0.016)\end{array}$ & $\begin{array}{l}-0.013 \\
(0.016)\end{array}$ \\
\hline Conscientiousness & $\begin{array}{c}-0.024 \\
(0.017)\end{array}$ & $\begin{array}{c}-0.026 \\
(0.016)\end{array}$ \\
\hline Emotional stability & $\begin{array}{c}0.034 * * \\
(0.017)\end{array}$ & $\begin{array}{c}0.033 * * \\
(0.017)\end{array}$ \\
\hline Openness to experience & $\begin{array}{c}0.024 \\
(0.016)\end{array}$ & $\begin{array}{c}0.023 \\
(0.016)\end{array}$ \\
\hline Locus of control & $\begin{array}{c}0.022 \\
(0.016)\end{array}$ & $\begin{array}{c}0.023 \\
(0.016)\end{array}$ \\
\hline Family income & $\begin{array}{c}0.005 \\
(0.017)\end{array}$ & $\begin{array}{c}0.005 \\
(0.017)\end{array}$ \\
\hline Parents' education & $\begin{array}{c}0.004 \\
(0.018)\end{array}$ & $\begin{array}{c}0.004 \\
(0.018)\end{array}$ \\
\hline Female*risk preference & $\begin{array}{c}0.024 \\
(0.029)\end{array}$ & $\begin{array}{c}0.023 \\
(0.029)\end{array}$ \\
\hline Female*confidence & $\begin{array}{c}0.006 \\
(0.016)\end{array}$ & $\begin{array}{c}0.004 \\
(0.016)\end{array}$ \\
\hline Female*ability & $\begin{array}{c}-0.021 \\
(0.031)\end{array}$ & $\begin{array}{c}-0.021 \\
(0.031)\end{array}$ \\
\hline Female*raven's test score & $\begin{array}{l}-0.017 \\
(0.015)\end{array}$ & $\begin{array}{c}-0.015 \\
(0.015)\end{array}$ \\
\hline Female*extraversion & $\begin{array}{c}0.003 \\
(0.015)\end{array}$ & $\begin{array}{c}0.003 \\
(0.015)\end{array}$ \\
\hline Female*agreeableness & $\begin{array}{c}0.017 \\
(0.015)\end{array}$ & $\begin{array}{c}0.015 \\
(0.015)\end{array}$ \\
\hline Female*conscientiousness & $\begin{array}{c}0.029 * \\
(0.015)\end{array}$ & $\begin{array}{c}0.031 * * \\
(0.015)\end{array}$ \\
\hline Female*emotional stability & $\begin{array}{c}-0.034 * * \\
(0.015)\end{array}$ & $\begin{array}{c}-0.033 * * \\
(0.015)\end{array}$ \\
\hline
\end{tabular}


Female*openness to experience

$\begin{array}{cc}-0.007 & -0.006 \\ (0.015) & (0.015) \\ -0.007 & -0.007 \\ (0.015) & (0.015) \\ 0.010 & 0.010 \\ (0.021) & (0.021) \\ 0.007 & 0.007 \\ (0.022) & (0.022) \\ 0.311 * * * & 0.311 * * * \\ (0.010) & (0.010)\end{array}$

Female*locus of control

(0.010)

Joint F-test on personality traits

1.55

(p-values)

$(0.098)$

(0.010)

Joint F-test on all RHS variables except female

3.04

1.56

(p-values)

Session fixed effects

Session-gender fixed effects

Observations

Yes

Yes
Yes

1946

0.175 $(0.096)$

R-squared

2.72

Notes: $* * * \mathrm{p}<0.01, * * \mathrm{p}<0.05$ and $* \mathrm{p}<0.10$. Robust standard errors in parentheses. See notes of Table 2 for variable definitions. 